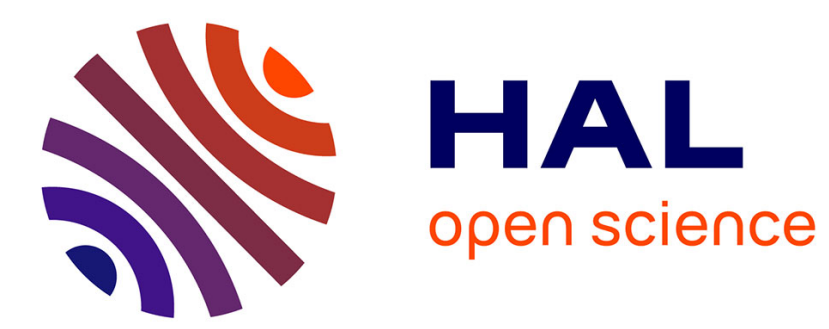

\title{
Shanghai Industries in the Civil War (1945-1947)
}

Christian Henriot

\section{To cite this version:}

Christian Henriot. Shanghai Industries in the Civil War (1945-1947). Journal of Urban History, 2015, 43 (5), pp.744 - 766. 10.1177/0096144214566977 . halshs-01765400

\section{HAL Id: halshs-01765400 \\ https://shs.hal.science/halshs-01765400}

Submitted on 12 Apr 2018

HAL is a multi-disciplinary open access archive for the deposit and dissemination of scientific research documents, whether they are published or not. The documents may come from teaching and research institutions in France or abroad, or from public or private research centers.
L'archive ouverte pluridisciplinaire HAL, est destinée au dépôt et à la diffusion de documents scientifiques de niveau recherche, publiés ou non, émanant des établissements d'enseignement et de recherche français ou étrangers, des laboratoires publics ou privés. 


\section{Shanghai Industries in the Civil War (1945-I947)}

Journal of Urban History 2017, Vol. 43(5) 744-766

(C) The Author(s) 2015 Reprints and permissions: sagepub.com/journalsPermissions.nav DOI: $|0.1| 77 / 0096|442| 4566977$ journals.sagepub.com/home/juh

@SAGE

\title{
Christian Henriot'
}

\begin{abstract}
This article examines the fate of Shanghai industries during the Civil War period in China. It argues that in spite of extreme difficulties in the later part of the war, Shanghai industries bounced back very quickly and reached early wartime levels within a year. Thereafter, a series of economic and political restrictions led to a slowdown, then a paralysis. The article is based on a large and unique survey of Shanghai industries published in October 1947, probably the peak of the economic recovery after the war. The data were processed in geographic information systems that the author implemented to examine what industry represented in the urban space, what its impact was, and how it defined the city of Shanghai. The author contends that issues of security more than economic factors determined the particular industrial geography in the city.
\end{abstract}

\section{Keywords}

China, Shanghai, war, industry, space

The present study of Shanghai industries focuses on the Civil War period, a phase of acute social and economic turmoil from the perspective of spatial history. ${ }^{1}$ Yet the selected time frame, as well as the nature of the major source on which this article relies, hardly allows for a study that incorporates a strong temporal dimension. The first part presents and examines the political and economic context of the postwar period in relation with the rebirth of Shanghai industries up to 1947. Hyperinflation in the following years just stifled this development. In the second part, I discuss the nature of the source and the methodology I used to process the collected data. This opens on a short analysis of the industrial structure and landscape in Shanghai. The last section explores the spatial dimensions of industries in the city for themselves but also in relation with various human and ecological factors, albeit tentatively. I argue that the late industrial development in Shanghai and the specific industrial structure produced a spatial arrangement that imposed a heavy industrial footprint throughout the city, much like the European cities of the first Industrial Revolution. None of the factors that drove factories and workshops out of central districts can be seen at work in the case of Shanghai due to considerations of safety and protection from war.

'Institut d’Asie Orientale, Lyon University (Lyon 2), France

Corresponding Author:

Christian Henriot, Institut d'Asie Orientale, Lyon University (Lyon 2), ENS de Lyon, BP 7000, Lyon cedex 07, 69342, France.

Email: christian.r.henriot@gmail.com 


\section{The Context}

The years 1946-1947 represent a turning point in the postwar period. During the preceding two years, the competition between the two major political and military contenders - the Nationalist government and the Communist Party of China (CCP) - had been brewing until it turned into an outright military struggle to take over the country. In March 1947, the Nationalist army even took over Yan'an, the wartime capital of the CCP. This victory buoyed the Nationalists' military fortune. Yet the highly symbolic victory proved short lived. After the summer, the Nationalist cause began to sputter. Communist armies began to score victories in North China. Then, from December 1947 to March 1948, Lin Biao's armies won a series of major battles in Manchuria. ${ }^{2}$ On the economic front, the situation worsened quickly. The serious wartime inflation intensified, making it increasingly difficult for the modern sector of the economy, especially industry, to take off again. Our "snapshot" of Shanghai industries in June 1947, therefore, provides a unique and effective picture of the strengths and weaknesses of this sector in times of increasing instability and turmoil.

Shanghai industries had come out of the war badly shaken. This was not due to military warfare, as the Japanese had acknowledged defeat without fighting after the surrender to the Allied powers following the atomic bombing of two Japanese cities. After November 1937, Shanghai had not experienced war again, except for a few American air raids on the industrial Yangshupu area in 1944-1945. Despite the curfew imposed on the population and measures to blind all lights at night, there was no major damage to the city and its industries. The demise of Shanghai industries was caused by two major nonmilitary factors. The first one was the ban imposed by the Allied powers on trade in all goods with Japan and its occupied areas after Pearl Harbor in December 1941. The blockade severely hampered Shanghai as the local industries relied heavily on imports of primary materials and on external markets as outlets for their products. The second factor was the system of controlled economy (tongzhi jingji) the Wang Jingwei government put in place in 1943 in a botched attempt to salvage the economy from crumbling further. ${ }^{3}$ The various state monopolies it actually created made the situation worse. Inefficiency, corruption, and the continued plundering of resources by the Japanese army in Central China stifled the sole alternative the domestic market could have offered to Shanghai industries. ${ }^{4}$ Finally, the liberal use of the printing machines to create money by both the Wang Jingwei government and the national government in Chongqing set an inflationary trend that proved fatal for industrial production. ${ }^{5}$ In June 1945, when victory was in sight but not yet achieved, an editorial of the Chinese Bankers' Weekly warned that this was the most serious crisis that trade and industry would face in the near future. ${ }^{6}$ This assessment proved to be right, although industry and trade encountered a host of other problems.

When victory was proclaimed in August 1945, relief was palpable in Shanghai. Despite the gloomy economic and social situation, people celebrated the end of the eight-year-long conflict and its attendant sequel of misery and anxieties. For a while, there was a genuinely festive atmosphere beyond the official ceremonies. People were proud that China had prevailed over Japan and "Victory" and the "V" sign soon became the most popular buzzword and new advertising catchword. People looked forward to a better future. ${ }^{7}$ Industrialists, too, could feel only relief at the end of the war and the elimination of the various stumbling blocks that had crippled their activity. The system of control economy was gone along with its genitor. More important, the ban on foreign trade was cancelled, and China was again part of the world economy. In view of the war legacy, they could expect postwar recovery to be an uphill march. Yet they probably did not imagine the walk would be so steep and that eventually they would stumble and roll down the hill at an even faster pace.

Shanghai industries had come a long way. By all accounts, and with very few exceptions, factories had sunk to near shutdown after $1944 .{ }^{8}$ Among the few sectors that escaped full paralysis, 
such as paper manufacturing, chemical and pharmaceutical industries, or leather processing, production remained well below the prewar level. ${ }^{9}$ This can be gauged from electrical consumption, at a historical low until the end of the war (40 percent of prewar level in 1943 against a peak of 105 percent in 1940). ${ }^{10}$ Textile mills, the backbone of Shanghai industry and the largest employer, were running at 10-15 percent of their capacities. ${ }^{11}$ As a result, all related sectors such as machine manufacturing, metal industries, dyeing, and so forth, also plunged to heretofore-unseen levels of inactivity. Many stopped altogether. ${ }^{12}$ Basically, manufacturers maintained a minimum level of production to prevent their machines from decaying in idleness and to retain on site a core group of technicians and workers to kick off production when the situation allowed. ${ }^{13}$ The city was not deprived of industries - there were an estimated 4,154 factories and probably five times more workshops. All that was missing were the conditions for a new departure in a more predictable environment.

Shanghai industries actually bounced back quickly as they seized all the opportunities to serve a domestic market in need of many goods, after years of shortage of all kinds, but also foreign markets, especially in Southeast Asia, where foreign competition had not yet returned. ${ }^{14}$ In early 1946, the Bankers' Weekly reported the reopening of factories in most industrial sectors. The forty-four factories seized by the Japanese army were returned to their owners to operate. All the cotton filatures, including the Japanese factories the National government confiscated, were up and running. ${ }^{15}$ Another sign of industrial vibrancy in the city was the first Industrial Products Exhibition (Shanghai gongyepin zhanlanhui) that showcased local manufacturers. It took place in March 1946, hardly nine months after the end of the war. ${ }^{16}$ The Shenbao devoted a special section to the exhibition for several days. The purpose was both to show the technological level of local industries and to emphasize the importance of technicians in economic development. ${ }^{17}$ People came from all over China, with a total attendance of about one hundred thousand. ${ }^{18}$ Industry was definitely again at the heart of development plans for China, not as a result of state intervention but due to the spontaneous drive by private entrepreneurs. In the postwar period, even more than before the war, the capacity of the state to support economic development dwindled rapidly, and what little connection remained with the private sector was fragmented and involved only short-term economic interests. ${ }^{19}$

There were genuine difficulties, such as chronic disruptions in domestic transportation or the persisting inflationary trend. On April 22, 1946, the Shenbao titled its editorial with a call to support Chinese industries. It highlighted four issues: unstable political situation, inflation, speculation, and workers' indiscipline. The newspaper warned that if the government failed to solve these issues, factories would again close down. ${ }^{20}$ Another more local pressing issue, adequate power supply, also slowed down industrial recovery. The power plants had not been able to renew or maintain their equipment properly. The Japanese had also caused some damage in an ill-designed attempt to transform the local machinery. In October 1946, the city produced 130,000 $\mathrm{kW}$, with two-thirds going to industry (42,000 $\mathrm{kW}$ to textile), while consumption peaked at $150,000 \mathrm{~kW}$ twice a day. ${ }^{21}$ Throughout 1946, there was insufficient power supply, although new machines were expected to boost production. In 1947, power supply still failed to catch up with industrial needs. ${ }^{22}$ To help manufacturers, the municipal government designed a system of quotas that curtailed individual consumption and limited the commercial use of electricity. Industrial concerns received most of the conserved energy, although this fell short of actual needs. ${ }^{23}$ The main issue was the lack of coal supply due to the emerging conflict in North China. Industrialists called for imports from Indochina.

Yet in the first year and a half after the Japanese defeat, the local industries made a solid recovery, with the creation of a large number of new plants. As the supply of primary materials was insufficient due to issues of transportation - increasingly this was linked to the expanding military conflict between the CCP and the National government-manufacturers relied again on imports, especially the textile industry. Cotton bales came in large quantities from the United 
States, Brazil, and India to feed the local cotton-starved mills. Several other sectors also drew their supplies from abroad to make up for local scarcity. While imports had a positive impact on industrial production, it also constituted a drain on China's reserves. In 1946, cotton imports alone represented one-half of all foreign imports. For the National government in need of foreign currency to pay for badly needed modern equipment or to support the $f a b i$, to see its reserves diverted to the purchase of a commodity that China could produce in abundance was not a sustainable prospect. Yet peasants had shifted away from growing cotton during the war, which placed total output at five million dan in 1945. The following years, output increased to 7.4 million and 10 million respectively, but it was still well below the prewar level of 12 million dan. ${ }^{24}$

By 1947, the National government started introducing restrictive measures on access to external markets and to curb industrial reliance on imports. On one hand, due to postwar confiscations of enemy properties, the government controlled directly a large chunk of the textile industry. ${ }^{25}$ On the other hand, through its financial arm, the Central Bank, the government had exclusive control over foreign exchange, albeit inefficiently. ${ }^{26}$ In January 1947, the government instituted a system of quotas for each industrial sector that defined the amount of money available for purchases abroad for a term..$^{27}$ The amount was revised periodically, with a strong competition between economic actors. ${ }^{28}$ While this scheme may have helped stabilize the drain on foreign exchange, the quota system constituted a return to strong government control of the economy, as under Wang Jingwei. It fell short of an outright "control economy" (tongzhi jingji), but if we include restoration of the National Economic Council and the establishment of various committees such as for the collection of raw cotton and its distribution among factories, the trend was unmistakable, albeit counterproductive. ${ }^{29}$ Chinese manufacturers again depended more on bureaucratic whim than on market demands. ${ }^{30}$ Repressive measures like the control of stocks, intended against hoarding and speculation, further compounded the difficulties of manufacturers. ${ }^{31}$

The most negative factor, however, was not so much this type of well-intended system of regulation than the inability of the government to curb inflation. The strong inflation carried over from the war period started to climb at an alarmingly high rate during 1946, with an eight-fold increase within a year, and it picked up speed soon again..$^{32}$ The increasing cost of primary materials represented a heavy weight on the competitiveness of Shanghai industries. Rising inflation also meant higher salaries for workers, especially after wages were pegged to the system of price indexes introduced by the government. There were repeated strike movements throughout the industry to demand higher wages when workers felt the index did not reflect their actual conditions or when the government once tried to suspend the index. ${ }^{33}$ By mid-1947, inflation spiraled off while the military fortune of the National government initiated its descent. As the war against the communist armies overrode all other concerns, the government printed increasing amounts of money to pay for its expenses, feeding further the devaluation of the Chinese currency. Eventually, hyperinflation set in and just killed all investment and production. The economy turned to barter and hoarding. By 1948, some manufacturers started to remove their operations to the south, to the safety of Canton or Hong Kong. ${ }^{34}$ After 1949, while the new regime strove to restore the economy, especially industrial production, it also definitely moved away from the market-driven system that had characterized Shanghai in the republican era.

\section{Sources and Methods}

My examination of the state of industries in the Shanghai urban space relies on a particular source that I processed in geographic information systems (GIS), like the industrial surveys of the Shanghai Municipal Council of the 1930s-1940s in a previous study. In the following section, I shall discuss first the nature of my main source, and then I shall explain the approach adopted to process and interpret the data. 
This study is based on a unique source: Shanghai zhizao changshang gailan (A Compendium of Shanghai Manufacturing Firms) published in 1947. ${ }^{35}$ There are only minimal indications about the purpose and initiators of this survey. Yet these indications point to a solid background in conducting such large-scale surveys. The introduction was signed by the "survey team" of the Union Credit Information Agency (Lianhe zhengxinsuo), a semiofficial agency established in March 1945 by a group of financial institutions. ${ }^{36}$ The Union Credit Information Agency actually produced numerous economic surveys, such as the massive Shanghai jingrongye gailan (An Overview of Shanghai Finance) in the same period or Tuchan jieshao (A Presentation of Land Properties) as late as $1951 .{ }^{37}$ There were very few such examples of extensive survey of industrial concerns in Shanghai. The Shanghai Chamber of Commerce published its own directory, Shanghai guohuo changshang minglu, also titled Shanghai Manufacturers Directory, in 1946. ${ }^{38}$ I identified another edition (1947) at the Shanghai Library. Another volume with a very similar title was published in 1934 , but there was no connection between the different publications. ${ }^{39}$

The Shanghai zhizao changshang gailan was prepared over the first half of 1947. It was completed in June and went to press almost without delay as the preface is dated October 1947. In other words, the survey presents a photograph of Shanghai industries almost exactly two years after the Japanese defeat and the return of the Guomindang to Shanghai. The data collected in this survey were based on the records of the professional organizations (tongye gonghui) in each industrial branch. It also included foreign firms, even if they were not members of the Chinese professional organizations. The information was collected either through written questionnaires or by direct visits to the companies. When information was not received, the survey team gathered data by indirect means. Despite its shortcomings, as discussed below, the Shanghai zhizao changshang gailan is an extremely valuable source. It probably reflects the closest we shall ever be able to get to the extent of Shanghai industries in the late $1940 \mathrm{~s}$ at a time when postwar industrial production reached a peak. ${ }^{40}$ The number of surveyed companies falls somewhere between an ideal but impossible registration of all factories and workshops and an exhaustive but restrictive survey of all factories according to the definition of the 1934 Factory Law. In other words, while the survey does not include all workshops, it goes way beyond the mere record of only the factories. To illustrate this dimension further, in February-June 1937, Shanghai hosted 5,525 factories and 28,651 workshops. Only 31 percent of the factories and 19 percent of the workshops were located in the foreign settlements. At the end of war in 1945, there were 4,154 factories. The number of workshops is unknown. ${ }^{41}$

Using this particular source raises several methodological issues. The first is definitely the incompleteness of information: there is a lack of consistent data on all aspects of the factories. The ambition was indeed very broad as it covered all companies present or represented in Shanghai and its surrounding districts. Yet even for the factories located intra muros, the ratio of incompleteness ranges from 40 percent (capital) to 62 percent (workforce). As incomplete data do not affect all factories in the same way, when comparing various parameters, the actual number of comparable data drops sharply (e.g., only 2,800 factories provide capital, workforce, and industrial sector). Even with these limitations, each subsample offers a solid basis with the sole caveat that I do not know exactly what I am missing. I can of course assume that missing data were more frequent about the smaller workshops. Yet I cannot fully rule out that data were missing for a few large companies. There are also inconsistencies, as I shall discuss later, for instance, companies with hundreds or thousands of workers and a capital merely equal to that of a workshop.

With a view to locate factories in the urban space, another major difficulty was in the labeling of street names in the survey. Street names were provided exclusively in Chinese, but they referred to various "name periods": current name, older Chinese name, older Western name in 
Chinese characters, and fully obsolete names. Obviously, having gone through successive waves of name change (especially in 1943 and 1945), factory owners put whatever came to their mind first, either out of habit or simply because they were not "up to date." The mix is extremely confounding, especially with the added difficulty that various major streets were divided into two (East, West) or three (North, Central, South) sections after 1945. In other words, even when using the 1946 commercial atlas as a base map, it was necessary to return to older maps to locate factories at the street number level. ${ }^{42}$ To compound difficulties further, the actual location of factories was not given as a street number but under the name of a particular lilong (alleyway). More than 2,500 factories listed their address in this way. A few even just gave the name of the lilong. In the absence of a historical georeferenced database of Shanghai lilong, there was no other choice than going through the maps and locating the factories one by one.

In this article, I processed as many factories as possible, but I was left with a backlog of some 1,500 factories awaiting further scrutiny. It is sometimes delicate to find a location in the foreign settlements, but when it comes to the Chinese-administered districts (in 1947, the city was under a single Chinese administration), the lack of adequate maps is a real pain. Whereas a detailed map for the former walled city and areas adjoining the former foreign settlements can be found in the 1946 commercial atlas, for most other areas (Nanshi outside the former walled city, Zhabei, Pudong), there are no maps that provide both the street names and street numbers for these areas, or even maps that would show lilong, particular features, etc. It is a serious methodological stumbling block that will persist as long as map repositories like the Shanghai Library or the City Archives continue to sit obstinately and uselessly on their map collections at the expense of scholarly research.

As indicated above, I will present elements of comparison between the situation in 1947 and that in the prewar and wartime periods. This comparison, however, is limited to the factories located in the International Settlement. It was the only area where the Shanghai Municipal Council carried out an annual survey starting in 1931. For the 1931-1936 period, this survey clearly missed all the factories located in the Chinese municipality. For the 1938-1940 period, due to the destruction of most factories in Zhabei and the move of many Chinese factories into the International Settlement, the population of factories in that territory offered a very representative sample of Shanghai industries. After 1940, it seems these surveys were discontinued. Only general statistics - number of factories, size of industrial workforce-are available. Another frustrating element is the difference in the data: The surveys in the International Settlement provided the nationality of the factories but not the Chinese survey; conversely, the Chinese survey provided the amount of capital and the year of establishment, which was missing in the Shanghai Municipal Council surveys. Our potential points of comparison, therefore, are limited to the workforce, industrial sector, and location.

In 1947, the survey covered not only Shanghai proper but the surrounding rural districts and companies represented in Shanghai, even if the factories were located elsewhere, sometimes in remote provinces. I removed a total of 310 factories located outside of the city proper, mostly in the rural counties around Shanghai (Jiading, Jiashan, Minhang, etc.). At the end of this elimination process, there remained a total of 9,443 industrial companies in the survey. The usable data in the survey cover a wide range: address, industrial sector, year of establishment, capital, workforce, and name of owner. The table below highlights the number of factories for which data were available in each category:

\begin{tabular}{llll}
\hline Street name & 9,443 & Workforce & 3,066 \\
Street number & 6,813 & Year & 3,796 \\
Street lilong & 2,443 & Capital & 5,694 \\
\hline
\end{tabular}




\section{Shanghai Industries in 1947}

In this section, I discuss a few variables that defined the state of Shanghai industries two years after the Japanese defeat. Altogether, some 3,796 companies indicated the year they went into production. The table below provides a summary of this industrial chronology. Of course, this does not represent all the factories that opened during each period, as many disappeared over time. Yet even if we take into account the process of attrition resulting from economic crisis, individual bankruptcy, and above all military conflicts, there is hardly any doubt that the pace of factory opening went up sharply after 1927. In other words, the expansion of industries in Shanghai followed a pattern by which after a slow growth between the mid-nineteenth century and the 1911 revolution, the number of factories increased more steadily in the early republican period, including during World War I, while the real explosion took place after the establishment of the Nationalist government in 1927. We still know very little about the actual structure of industries during this early phase and even less about their distribution in the city and the factors that drove industrialists to elect a place for industrial production.

In a previous study of prewar and wartime industries, I established that there were around 1,200-1,300 factories in the sole International Settlement in 1935-1936. This number dropped to slightly over eight hundred after the military conflict of 1937. Yet Shanghai industries resumed their growth during the war with close to 1,900 factories in the International Settlement alone in $1940 .{ }^{43}$ By that time, the settlement probably concentrated most of the factories in the city. Yet the Japanese occupation changed again the political landscape, while the stabilization of power under Chen Gongbo in the Chinese municipality may have induced new developments. There is, however, no survey of industries during the 1940-1945 period.

In view of the ratio of turnover I have observed during the 1930s, including the extensive damages resulting from war, there is little chance that the rate of turnover in the World War I period or the decades thereafter could have exceeded that of the 1930s. In other words, even with a high attrition rate, the number of factories that emerged during and after World War I clearly represented the beginning of a process that never stopped, despite civil disorders and military conflict in the city. If the Nationalist era represented the end of the golden age of the bourgeoisie as a political actor, it was definitely not the end of its role and influence as an economic actor. ${ }^{44}$ Industry continued to flourish against all odds and remained firmly in private hands.

Table 1 shows that a large share of factories had a long history, with 10 percent in existence before 1927, including 119 plants (3.1 percent) established during World War I and 228 (6.0 percent) in the "years of crisis" that followed. Those dating back to the imperial period represented only 39 factories ( 1 percent). Yet this is to be expected in view of the initial small number, risky ventures, and inevitable commercial failures. The three major sectors that emerged during this early period were construction industry, printing, and textile, representing 62 percent of all surviving factories. Table 1 also demonstrates that there was a sustained and formidable thrust for the establishment of factories. I have divided the chronology into subperiods that take into account major events (such as the Sino-Japanese War) but also what appear to be genuine thresholds in terms of factory creation. This approach may be debatable as it is based on the state of surviving factories as of 1947. Logically, the number of more recent factories surpassed those of factories created in the previous decades. As the subperiods were uneven in terms of duration, I calculated a ratio per year that highlights the unwavering and increasing trend in factory creation throughout the whole period. These figures provide a mere indication, as we know that the actual number of factory creation in a single year was much higher. It is striking to note that in the immediate postwar years, on average 431 new factories were established, although 1946 marked a peak (725) followed by a clear slowdown (hypothetically 272) in 1947. These figures mean that industry left a substantial footprint in the city since World War I in a context of low regulatory 
Table I. Year of Foundation of Shanghai Factories in 1947.

\begin{tabular}{lccc}
\hline Period & Number & Ratio/year & Percentage \\
\hline $1851-1895$ & 17 & 0.4 & 0.4 \\
$1896-1911$ & 22 & 1.5 & 0.6 \\
$1912-1918$ & 119 & 17 & 3.1 \\
$1919-1926$ & 228 & 28 & 6.0 \\
$1927-1937$ & 1141 & 103 & 30.0 \\
$1938-1945$ & 1412 & 176 & 37.1 \\
$1946-1947$ & 862 & 431 & 22.7 \\
Total & 3801 & & 100 \\
\hline
\end{tabular}

constraints. As I discuss in the next section, industries colonized the urban space during the two decades before 1947 and established a particular spatial imprint in the city.

The role of the state in this process was negligible, even during the Nanjing decade, and there is hardly any substantial evidence to link this development to the role of a "developmental state." Quite to the contrary, the fiscal policy of the central government injured various industrial sectors. The dismal performance of the state was even more evident in 1938-1945, when the Nationalist government withdrew to Chongqing and lost all control over Shanghai. The remarkable resurgence of industries in 1938-1941 resulted only from the dynamic private entrepreneurs. ${ }^{45}$ While the state returned to the city in 1945 with a determination to claim a central role in economic reconstruction, including direct control on major confiscated textile companies, the impressive number of newly created factories in the postwar period resulted from the initiatives of the private sector. In the two years after victory, the Nationalist government hardly had the time, the means, and the instruments to reenact the policy through which it had built an industrial state sector in unoccupied China during the war. The NEC received no more than 1 percent of the funds to meet its plans. ${ }^{46}$ Moreover, the direct involvement of the state had focused on very strategic industries, especially ordnance, steel, oil, etc., yet with a dismal result in terms of economic results. Most of the companies had an extremely low return on the huge investment made. ${ }^{47}$

The structure of ownership is not apparent in the processed data, but it tends to confirm the role of individual entrepreneurs. Most factories were owned or managed by a single individual. This analysis is based solely on the names listed as owner or manager for factories. There were only 22 cases for which two or three names were provided as co-owners or managers. Out of a total of 9,443 factories, 8,049 came under a one-man ownership or management. Shanghai's industrial structure was clearly made up of a myriad of individual factories and workshops. Yet naming the manager rather than the owner introduced a certain bias, as actual investors did not appear. Cases of multiple ownership/management were pretty rare beyond owning two factories. Whereas 405 industrialists owned or managed two factories, only 75 ran three, 23 ran four, and 18 ran five or more. The most exceptional case was that of Rong Hongyuan (荣鸿元). Rong owned 11 factories, most of them in the textile industry with a total workforce of eighteen thousand workers. Rong was actually the main representative of the Rong family's industrial empire, including the famous Shenxin Cotton Mills. ${ }^{48}$ Du Yuesheng, the infamous head of the Green Gang, came second with 10 in textile, printing, paper, rubber, and food. Other exceptional cases include Li Fucai, head of the Jinglunsheng group in woolen textiles (9 factories); Jin Zongcheng, owner of a diversified group of 9 factories (textile, chemical, metallurgy, electric, machine manufacturing); Fang Jiyang, who operated 8 factories, mostly in cosmetics and soap; and Cai Shengpai, head of the Meiya group of textile mills (8). 
The city's recorded industrial workforce in 1947 stood at 335,018 workers. Since the survey is incomplete, the actual figure must have been higher. Only 3,069 factories - about one-thirdprovided a figure for their workforce. Nevertheless, there is a high probability that mostly small factories failed to answer or were overlooked by the surveyors. This could place the missing workforce at about 60,000 (6,000 $\times$ average 10/factory). There are, of course, other various figures for the industrial workforce, but they vary, depending on the criteria adopted to define it. The Shanghai Municipal Police made the most accurate assessment for the International Settlement between 1931 and 1940. Yet it took into account only the factories with 10 workers and more. In the latest known survey in 1940, the industrial workforce stood in the settlement at 226,657. Based on the same criteria, the 1946 workforce represented 331,342 workers, a gain of 104,685. Yet as neither the French Concession nor the Chinese municipality was included in the 1940 survey, this may just represent their share of the workforce.

Yet if we compare this with the size of the industrial workforce in the last years of the war, there can be no doubt about the fantastic progress and recovery after 1945. In the latter part of the war, the rising cost of energy and the curtailment of the production of electricity became a severe impediment to the operation of industrial plants. The authorities of the two foreign settlements had imposed heavy tax surcharges and introduced consumption quotas. ${ }^{49}$ After Pearl Harbor, the real issue was about the brutal decline in coal supply, which in turn caused the production of energy to drop sharply. ${ }^{50}$ By 1942, the general level of production of electricity was half that of 1936. ${ }^{51}$ In December 1943, energy quotas were lowered even further. At this level, Chinese factories could use only 5.5 percent of their productive capacity. ${ }^{52}$ In mid-1943, there were 1,617 plants in operation. On average, industrial firms had lost 58 percent of their workers. ${ }^{53}$ In February 1944, there were 4,607 enterprises employing more than 10 workers in the city. Of these 4,607 enterprises, however, only 2,910 (63 percent) were in operation. The strongest sectors - machine (1399) and textile (841) industries - employed altogether 87,041 workers. ${ }^{54}$

If we are to judge solely by the number of factories, the increase in the number of factories $(2,910 / 4,607)$ and size of the workforce $(87,041)$ between 1944 and 1946 was amazing. The progression in the textile industry, from 24,752 to 209,950 , revealed a formidable comeback of Shanghai industries to the early wartime level. In other words, in the immediate postwar period, Shanghai industries recovered promptly and started again to churn out much-needed industrial goods, with textile clearly moving ahead of all other sectors. The workforce was very unevenly distributed among the various industrial branches. Textile dominated, evidently, with 30.7 percent of the factories but 62.5 percent of the workforce, a level quite similar to prewar and wartime industry. The next most significant sectors came far behind in terms of workforce: tobacco (6.9 percent), rubber and plastic (4.9 percent), food (4.1 percent), chemical industry ( 3.4 percent), and printing (3.3 percent). A very dynamic sector, metallurgy, represented one-fifth of all factories ( 21.8 percent), yet with a small share of the workforce ( 3.1 percent). This pointed clearly to a particularly diffused mode of production. Shanghai remained definitely a textile production center, yet with a wide variety of industrial activities behind its industrial walls.

Shanghai industry in 1947 was made up of a host of small-scale factories and workshops (Table 2). Depending on whether most small factories simply did not respond, this could of course alter very much our view. Yet it would only emphasize more the share of small-scale factories with little impact on the overall picture of industrial workforce. The workforce was distributed between two major poles. One-third of the factories had fewer than ten workers and another third had fewer than fifty workers. Yet altogether they represented only 9.2 percent of the total workforce. At the other end of the spectrum, the largest factories with more than one thousand workers represented 2.0 percent of all factories but 43.3 percent of the industrial workforce. In other words, the top twenty-seven factories weighted almost as much as the bottom 1,052 workshops. In between, a quarter of the plants employed about 47 percent of the workers. The high 
Table 2. Size of the Workforce in Shanghai Factories.

\begin{tabular}{lrrrr}
\hline Workforce & Total & Percentage & Factories & Percentage \\
\hline$<10$ & 4,784 & 1 & 1,052 & 34 \\
$10-49$ & 26,251 & 8 & 1,124 & 37 \\
$50-299$ & 80,717 & 24 & 664 & 22 \\
$300-999$ & 79,030 & 24 & 169 & 6 \\
$1,000-1,999$ & 41,516 & 12 & 33 & 1 \\
$2,000-8,000$ & 103,828 & 31 & 27 & 1 \\
Total & 336,126 & 100 & 3,069 & 100 \\
\hline
\end{tabular}

number of small-size factories was a major factor in defining the spatial distribution of industry in the city.

A total of 5,699 factories provided figures about their level of capitalization. Due to the rampant inflation, these figures looked very impressive. To facilitate the reading, I converted all figures into US dollars based on the rate given in Chang Kia-ngau's classic study of Chinese inflation. I applied the market rate of $36,826 \mathrm{CNC} / \mathrm{US} \$ .{ }^{55}$ The total value of known industrial capital in Shanghai amounted to $\$ 29.5$ million $(\$ 29,534,730)$. Since 4,249 factories failed to report their capital, we may be missing a substantial chunk of actual value. Based on the average value $(\$ 5,187)$ of the 5,694 known factories, the missing value might amount to almost $\$ 20$ million $(\$ 19,903,379)$. Yet most of the underreporting was linked to the small-scale factories. The factories in the two lower levels of capital-under $\$ 100$ and $\$ 100-\$ 499$-represented respectively 35.4 and 37.1 percent of all factories, but they owned only 1.2 percent of industrial capital. At the other end of the spectrum, the 39 factories with capital above $\$ 100,000$ represented only 0.4 percent of all factories, but they owned 62 percent of all industrial capital. Textile industries came ahead of all other sectors in terms of capitalization, with close to threequarters of industrial capital. War failed to fundamentally alter the industrial structure of the city. ${ }^{56}$ This high degree of concentration had many implications not only in economic terms but also on the spatial pattern industry carved within Shanghai. It also meant the industrial policy by the national government intended to focus on this group of "heavy weights," especially the nationalized companies.

Combining the figures for industrial branch and workforce still makes textile the leading sector of Shanghai industries. My figures are incomplete since the survey provided workforce data for only 3,066 factories. In Table 3, I ordered the data by size of the workforce. Factories are listed in two separate columns, one for the total number of factories and one for those that came with data on their workforce. With 62.5 percent of all workers, textile ranked first, even if the sector was made up of a huge number of plants $(3,905)$. The next most important sector was metallurgy with 1,261 plants, yet with a very small share of the workforce. This indicates that most were small workshops with only one or a few workers.

\section{Shanghai Industries in the Urban Space}

What does GIS add to our understanding of the place and impact of industries in the urban space and the "eco-system" in Shanghai? One can examine these issues from various angles, but this examination depends on how much data one can gather on other aspects of urban life and how far these data can match the industrial data. At stake are issues of temporality (series do not overlap), space (series cover disconnected areas), data construction (series linked/unlinked to spatial entities), etc. In the section below, I propose a spatial reading of industries that aims first at defining what kind of a city Shanghai was in the late 1940s. 
Table 3. Distribution of Factories and Workforce by Industrial Sector (1947) (workforce above I,000/ sector).

\begin{tabular}{|c|c|c|c|c|c|c|}
\hline \multirow[b]{2}{*}{ Industrial branch } & \multicolumn{2}{|c|}{ Workforce } & \multicolumn{2}{|c|}{ Factories } & \multicolumn{2}{|c|}{$\begin{array}{l}\text { Total number of } \\
\text { factories }\end{array}$} \\
\hline & Total & Percentage & Total & Percentage & Total & Percentage \\
\hline Total & 335,018 & 100.0 & 2,620 & 100.0 & 9,444 & 100.0 \\
\hline Textile & 209,150 & 62.4 & 940 & 35.9 & 3,903 & 41.3 \\
\hline Tobacco processing & 23,305 & 7.0 & 62 & 2.4 & 106 & I.I \\
\hline Rubber and plastic products & $|6,3| \mid$ & 4.9 & 56 & 2.1 & 119 & 1.3 \\
\hline Food industry & 13,873 & 4.1 & 120 & 4.6 & 225 & 2.4 \\
\hline Chemical industry & 11,199 & 3.3 & 146 & 5.6 & 266 & 2.8 \\
\hline Printing & I I,057 & 3.3 & 235 & 9.0 & 541 & 5.7 \\
\hline Machinery manufacturing & 9,005 & 2.7 & 167 & 6.4 & 758 & 8.0 \\
\hline Metallurgy & 8,201 & 2.4 & 223 & 8.5 & 565 & 6.0 \\
\hline Electric equipment & 7,905 & 2.4 & 153 & 5.8 & 238 & 2.5 \\
\hline Paper processing & 6,525 & 1.9 & 207 & 7.9 & 222 & 2.4 \\
\hline Nonmetal mineral products & 5,805 & 1.7 & 43 & 1.6 & 122 & 1.3 \\
\hline Pharmaceutical industry & 4,936 & 1.5 & 17 & 0.6 & 91 & 1.0 \\
\hline Construction industry & 3,188 & 1.0 & 92 & 3.5 & 924 & 9.8 \\
\hline Metal products & 2,090 & 0.6 & 446 & 17.0 & 696 & 7.4 \\
\hline
\end{tabular}

My first observation is that Shanghai was a city of production that hosted most of its factories and workshops in the city proper, even if some particular areas received the largest concerns (Map 1). Nevertheless, if one takes the racecourse as the central point of reference for "downtown," one can see that most industries were located within a short range from this point. This is not trivial in terms of the various factors that conditioned the operation of factories:

- Transportation: primary materials, finished products, exchange between factories

- Modes of transportation: human labor (handcarts, boats), trucks

- Channels of transportation: Soochow Creek, Huangpu River, canals, and creeks

It is also significant in terms of several aspects of urban life: environmental impact (noise, fumes, waste water, etc.), human traffic (on foot, bicycles, public transportation), housing (of workers, of neighboring residents), and real estate value (pull/push effect). On most of these, however, there is little actual data I can rely on at this stage, but nevertheless I shall explore their significance for Shanghai urban space.

At first glance, factories and workshops could be found everywhere in the city in the late 1940s. Yet one can also note a "T"-shape distribution with the horizontal bar spread along the line formed by the Soochow Creek and the upper East-West section of the Huangpu River. The vertical bar of the $\mathrm{T}$ is a fairly thick trunk west of the lower North-South section of the Huangpu River. The sheer distribution, however, tends to mask inequalities in spatial distribution. By introducing a grid that averages the number of factories on the same basis, I obtained a map that highlights much more the highest densities of plants (Map 2). It revealed a thick ribbon along Soochow Creek and a less obvious pattern in the southern part of the city. Yet what it highlights is the substantial presence of industrial establishments in the core areas of the city. One could even argue that in the late 1940s, Shanghai was structurally very similar to Paris in the latenineteenth century when industrial concerns and workshops were concentrated intra muros. By the 1940s, however, large factories and many small establishments had already moved away to 


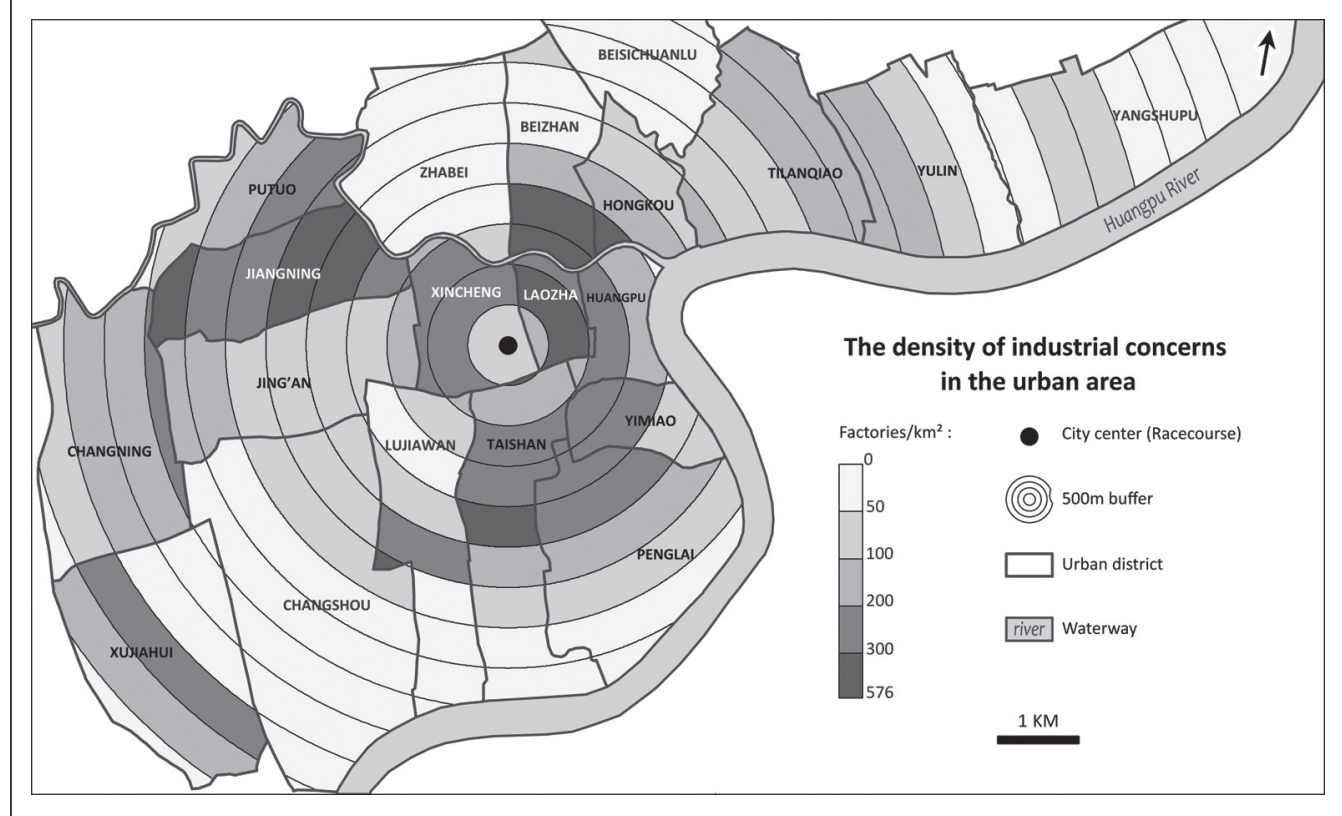

Map I. The density of industrial concerns in the urban area.

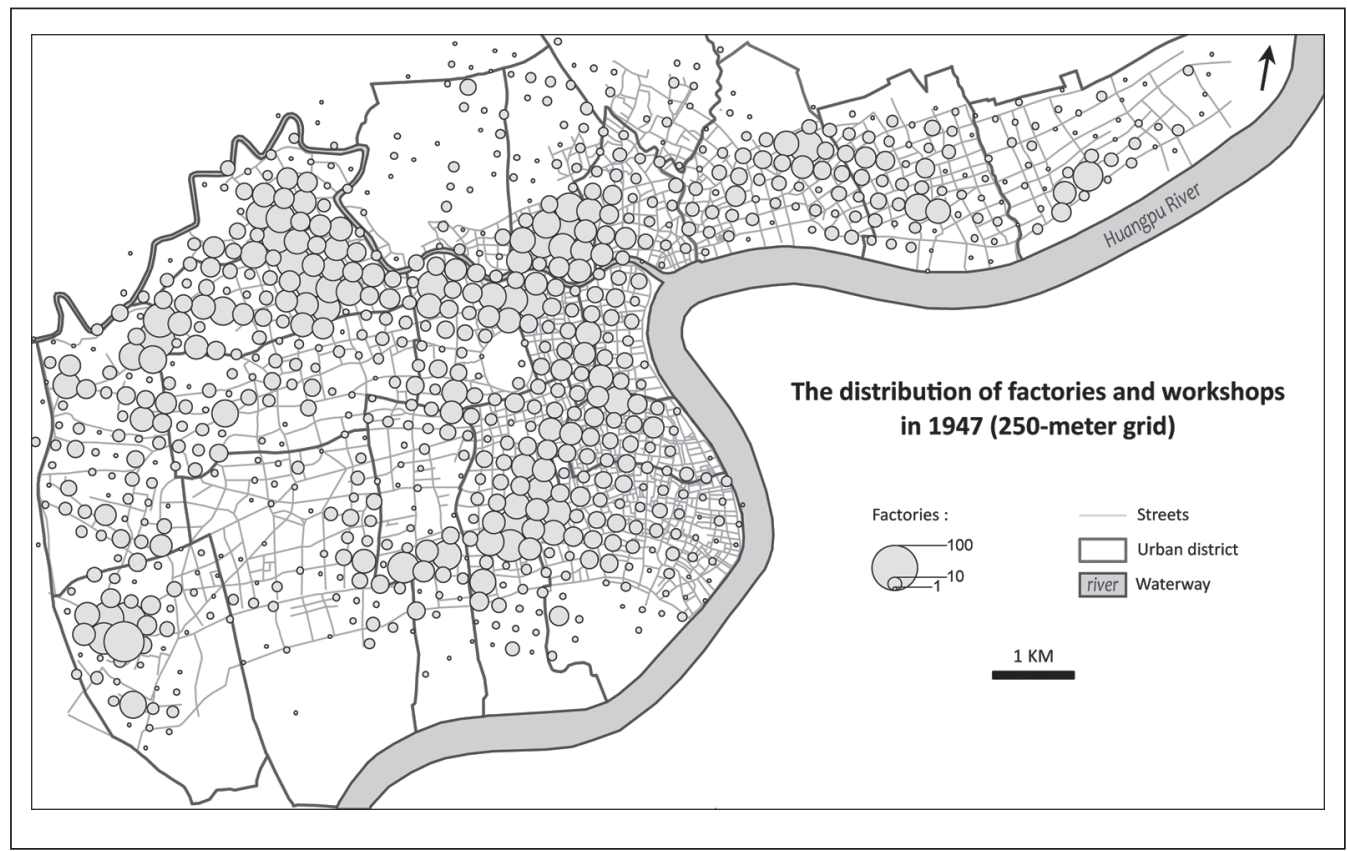

Map 2. The distribution of factories and workshops in 1947 (250-meter grid). 
industrial suburbs. ${ }^{57}$ By and large, the abnormal situation of Shanghai bears some similarity to Saint Petersburg, where land value and rent hardly had any effect on factory location in mid- to late-nineteenth century, with most factories scattered throughout the city. Neither did the deglomerative pressures from escalating property values cause any sort of significant exodus, even if industry colonized a few peripheral boroughs. Unfortunately, this study stops at $1913 .{ }^{58} \mathrm{In}$ Shanghai, increased rents and raising land values failed to dislodge the multitude of workshops and factories from the urban area. Apart from the issue of transportation facilities, a central factor in this urban concentration may have been the degree of security the city guaranteed, especially as long as the protected foreign settlements were in existence. ${ }^{59}$ Despite a favorable flat terrain, there were no sprawling industrial districts outside the central city and beyond as occurred in Pittsburgh between 1870 and $1920 .^{60}$

All factories were not equal as I discussed above. Capital endowment varied greatly. Map 3 provides a general view of the distribution of industrial capital in the city. There was a striking imbalance between the few "heavy weights" concentrated in very few places and the majority of small plants and workshops. A grid-based map made this more explicit, although it tended to tone down a bit the discrepancy. In fact, if we take the two extremes of capital value, the factories with less than $\$ 100$ of capital actually formed the T shape discussed above. These factories were almost everywhere. Conversely, if we take the factories with the largest capital, the "jewels" of Shanghai's industries were located in two main areas, the middle section of Yangshupu along the Huangpu River and the western districts (with a much higher number). These large factories needed large tracks of land that they found at affordable prices in the less developed areas in the eastern and western parts of the city, even if by 1947 urbanization had started to catch up, at least in the West. Obviously, this was a historical legacy that three decades of urban development had not yet challenged. Capitalization, however, remains an abstract indicator. It does say something about the wealth invested in the factories, hence in the areas where they were located. To get closer to work, production, and urban life, however, I shall take a look at the people who worked in these establishments.

The size of the workforce provides a parallel although not entirely symmetrical perspective to capital. Factories and workers were present throughout the city. The two main concentrations discussed above remain very obvious, with the addition of a secondary ribbon of large plants on an East-West axis in the southern part of the city. The grid-based map makes this pattern more visible. If I retain only the largest factories above eight hundred workers, I can find again the three main "industrial nexus". What actually lay behind this particular distribution is the domineering role of one sector, the textile industry, and within this sector, as we shall see below, the large cotton mills. By and large, the large-scale factories all belonged to the cotton industry (Map 4). Although the silk industry included a few fair-sized establishments, it represented a minor contribution compared to cotton mills. The silk industry never fully recovered from the mid-1930s crisis and the postwar difficulties in getting supply.

This distribution reflected a long-established pattern resulting from a combination of objective factors such as the proximity of rivers for certain types of industrial production, especially textile (see below), and the enforcement of more or less restrictive regulations on the location of factories, as in the former French Concession. It is possible to compare the situation in the former International Settlement in 1940, probably almost the peak year during wartime, and in 1947. For the silk industry, the situation was almost stationary. There was no noticeable change despite the issue of comparable data. For different reasons that mostly have to do with the scale of cotton mills, change was also limited in the cotton industry, even if a few companies disappeared and new ones opened. Yet without effectively tracing the companies by name, there is a risk to overinterpret these results. Again, it may reflect the lack of data (data on location but not on workforce).

By 1947, the previous regulations no longer applied. Factory owners established their plants much more freely in the city than before, especially those that required smaller premises. This 


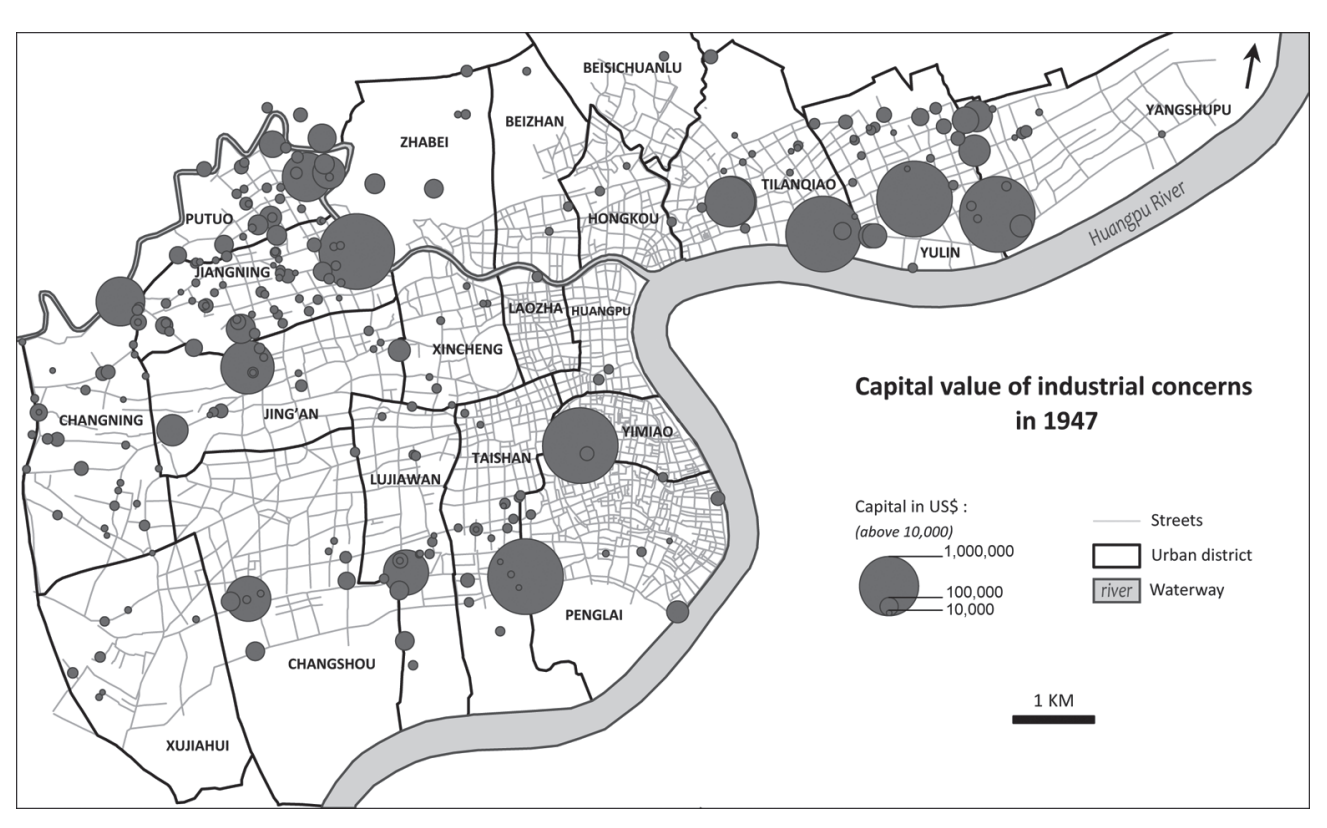

Map 3. Capital value of industrial concerns in 1947.

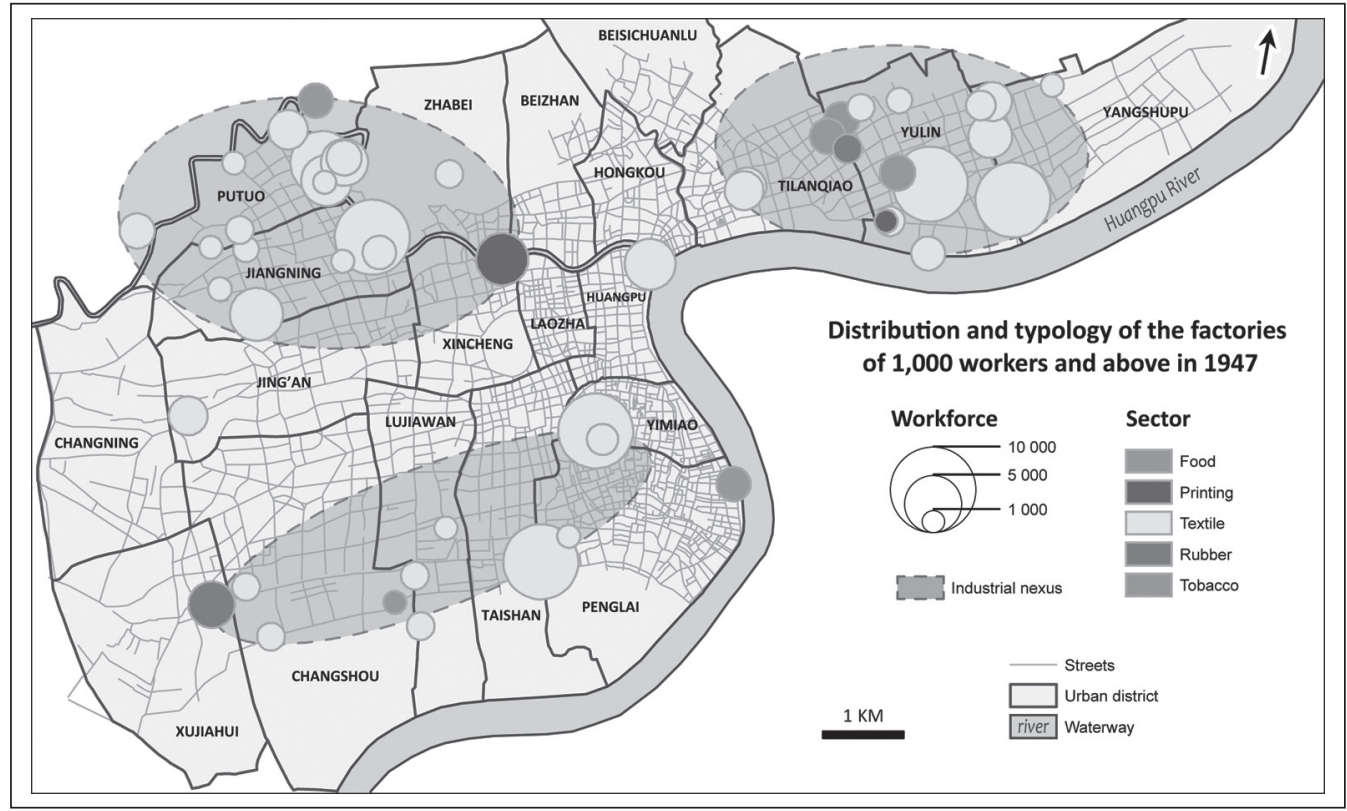

Map 4. Distribution and typology of the factories of I,000 workers and above.

would explain the presence of a large number of small-size factories in the core urban areas, despite the higher cost of real estate. Some sectors that developed in the postwar period seem to exhibit such a pattern, such as the food industry, printing (Map 5), or machinery (Map 6). 


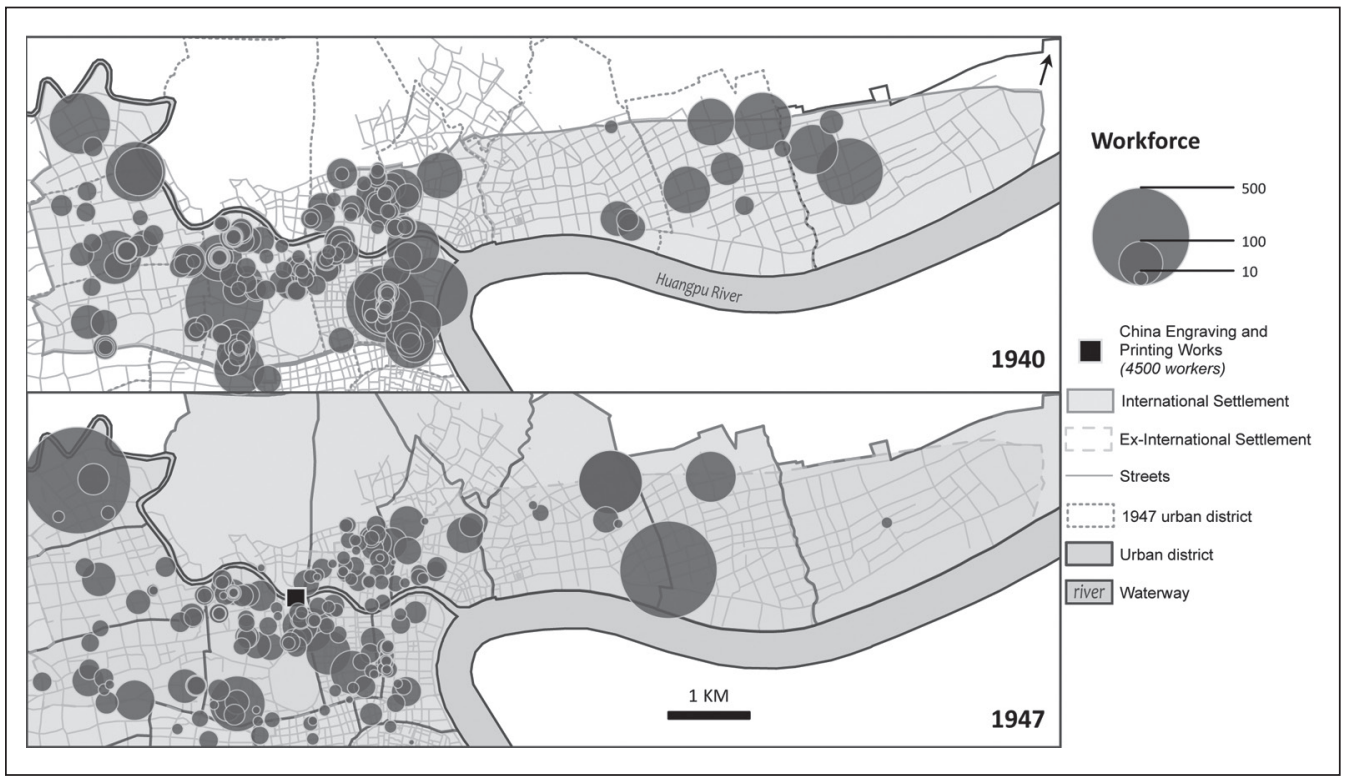

Map 5. The distribution and workforce of printing factories in 1940 and 1947.

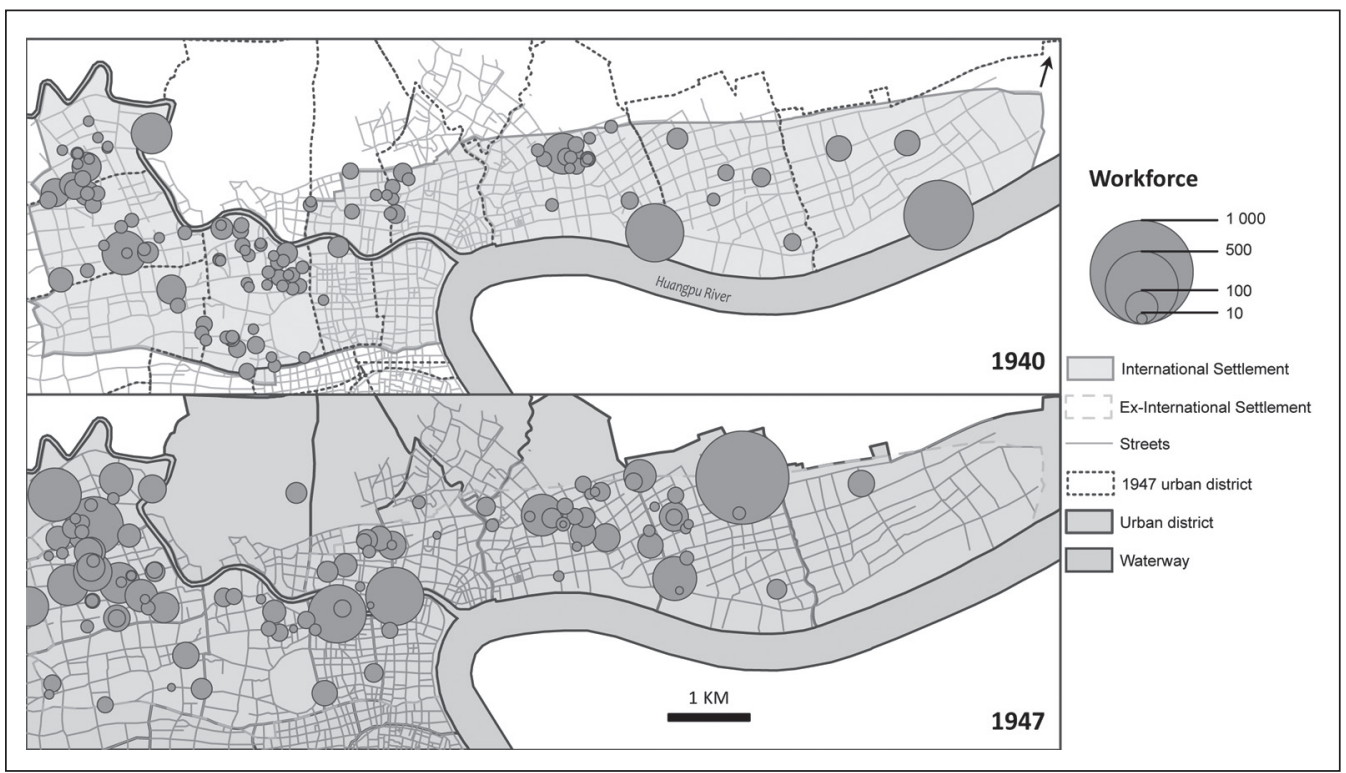

Map 6. The distribution and workforce of machine manufacturing factories in 1940 and 1947.

For these mostly smaller establishments, the issue of transportation costs or facilities overrode the consideration of rent for their premises. I make the hypothesis that this was a factor for plants that served the needs of other factories in machinery, repairs, metal parts, etc. There is no way at this stage to ascribe a "linkage factor" to the pattern of spatial distribution or to weigh the respective share of different factors (real estate, transportation, etc.). I can observe 


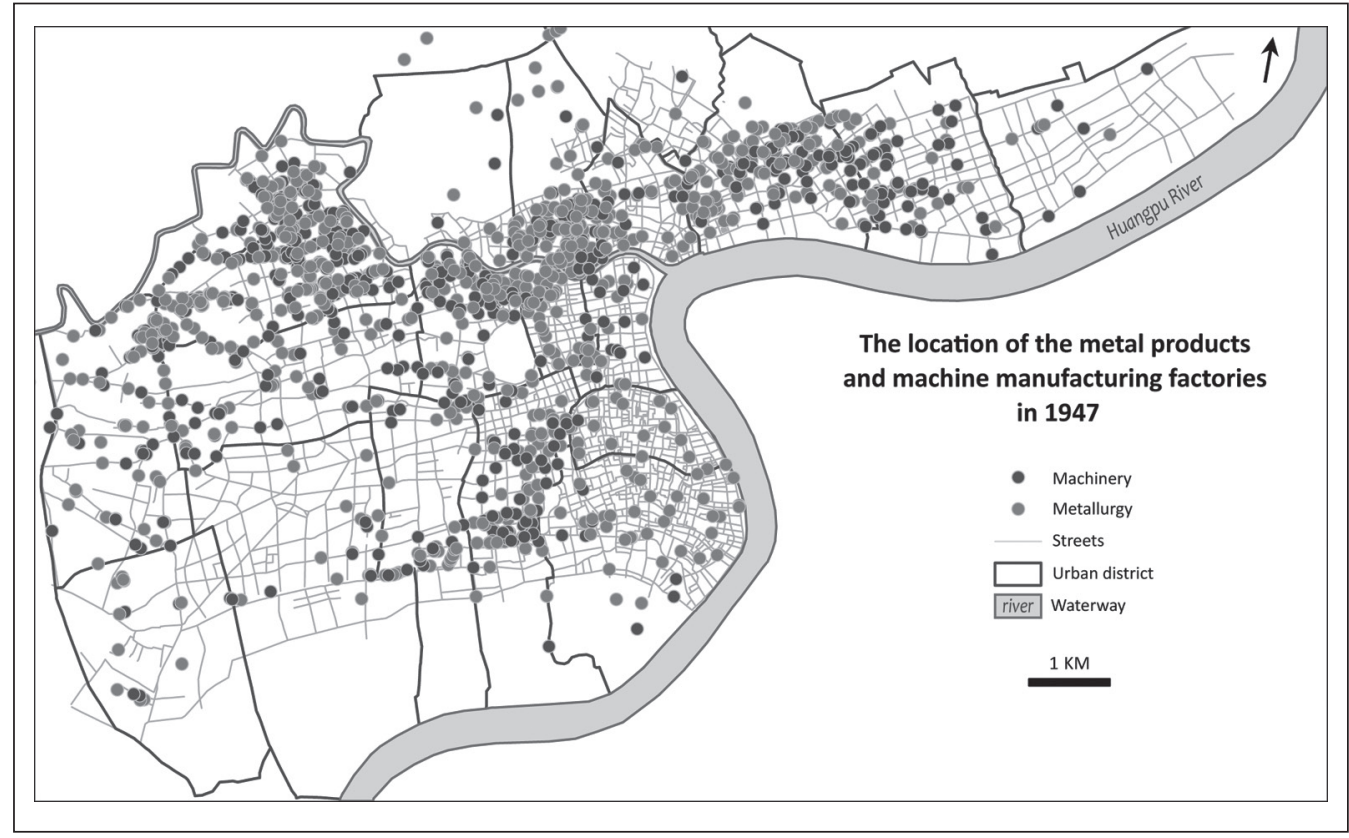

Map 7. The location of the metal products and machine manufacturing factories in 1947.

that related sectors like metal and machinery, machinery and textile, or paper and printing formed highly visible clusters (Maps 7-8). Yet to establish clear correlations will demand further analysis. Another development was the multiplication of factories in the western periphery of the city - the contested Huxi area-during the war. ${ }^{61}$ Although I cannot assign clearly these developments to the wartime period or to the postwar period, there was a substantial colonization of urban space by industrial establishments almost everywhere, except in the former western residential areas.

The general perspective I have presented on Shanghai industries in the previous section certainly does not do justice to their multifaceted impact on the city. Factories were physical premises in which workers transformed primary materials or semifinished products. Beyond their occupation of a more or less extensive piece of land and their direct influence on their surroundings (land, air, water), factories represented constant flows of goods and people coming in and out of the premises. While workers usually came over surface streets, the transportation of goods was carried out on both land and water. Factories were also places of social tensions that could lead to work slowdown and outright strikes that would spill over the streets. There would be a challenge for the authorities to contain such labor movements. How much of this can we apprehend through GIS?

The distribution of industrial concerns created a specific network of "industrial streets" that received the flow of workers on their way to and from work (Map 9). On their way, they patronized the cheap roadside peddlers and restaurants. Although many lived on low income, it did not fully exclude the presence of ancillary services geared toward these low-income workers. The movement of goods also induced an activity on the streets as a large part of local transportation was made on handcarts, wheelbarrows, or pedicabs. This was human labor, hence another layer of laborers in the streets. The waterways, not just the two main rivers but also the network of canals that still pervaded the Shanghai urban space, were also a privileged mode of transportation to ship goods in and out of the plants. The proximity to rivers was a major factor in the location 


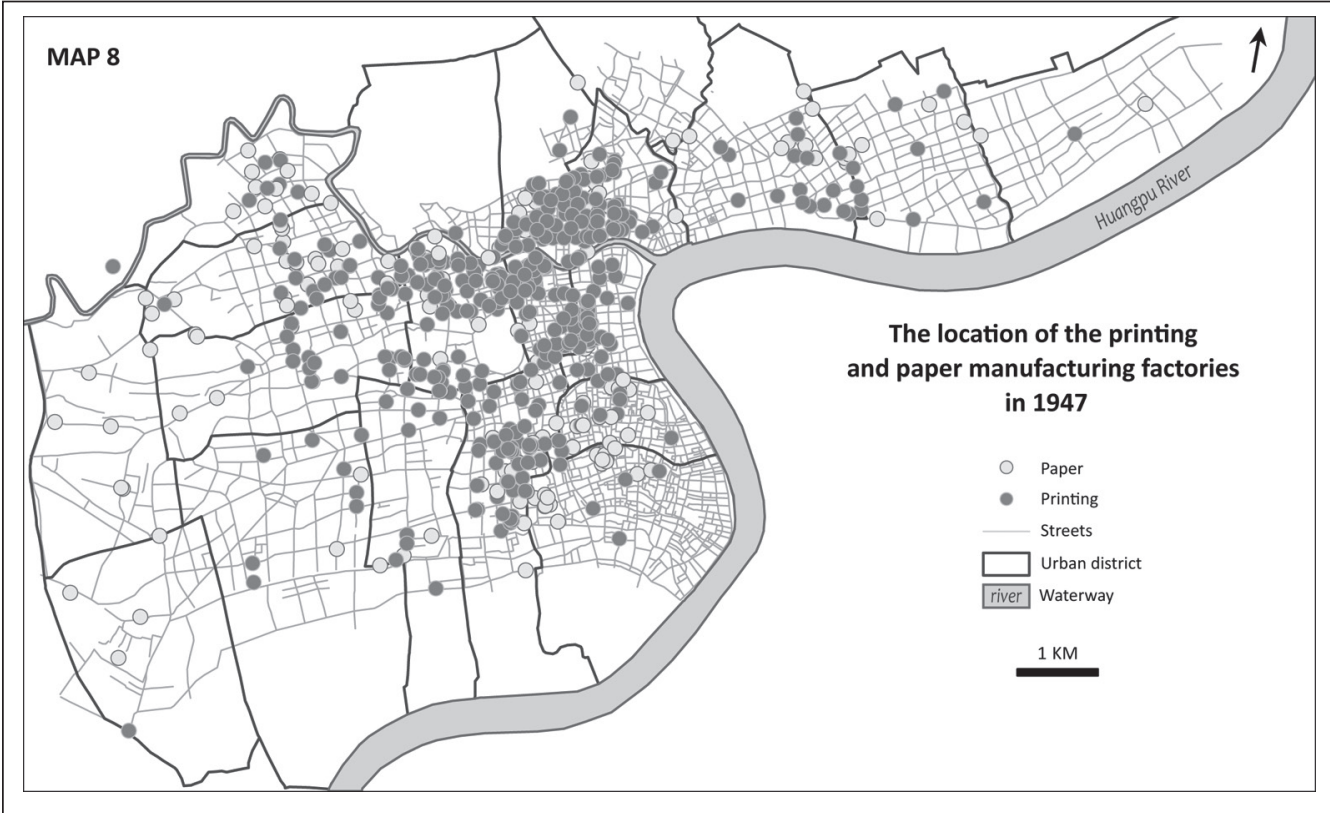

Map 8. The location of the printing and paper manufacturing factories in 1947.

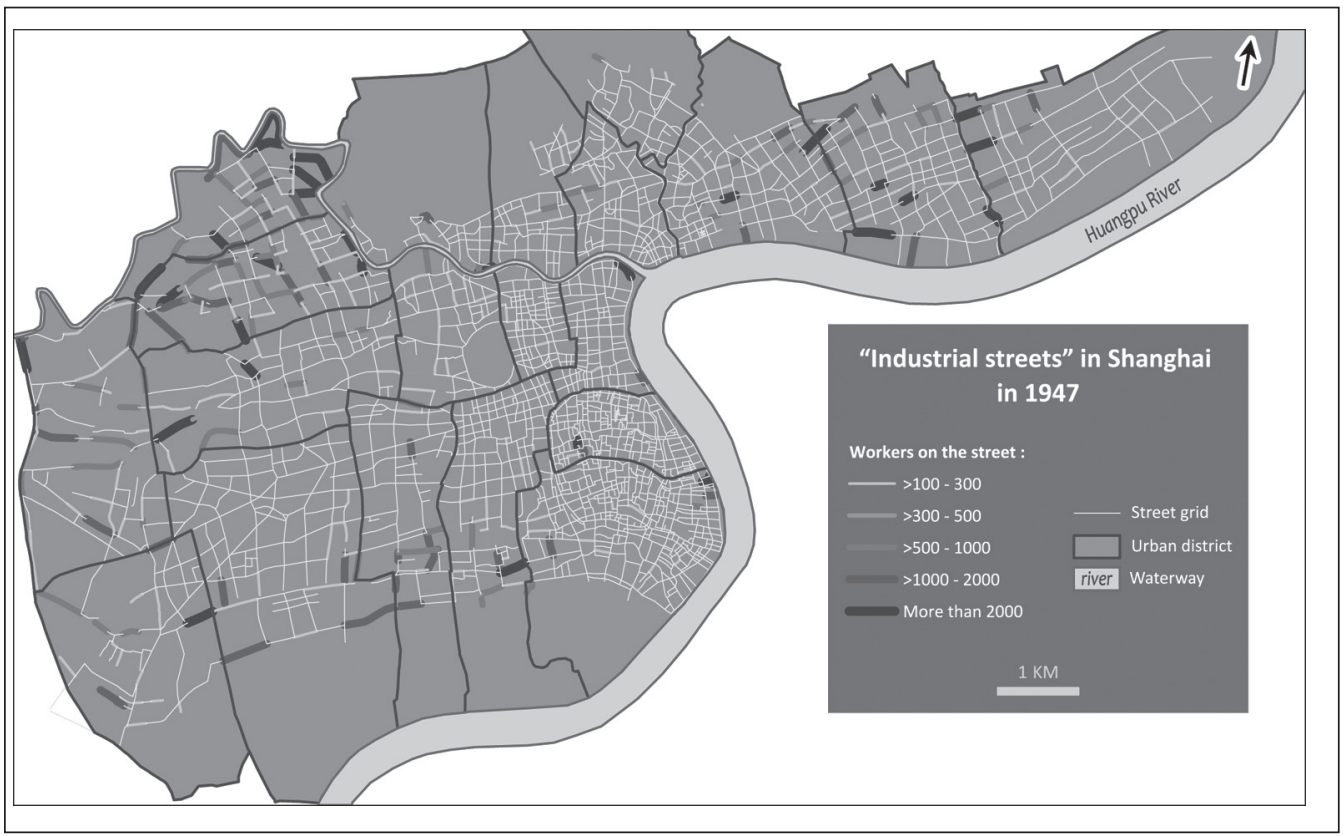

Map 9. "Industrial streets" in Shanghai in 1947.

of textile factories because of both their needs for transportation and for water to clean, process, or dye the textile fibers. 


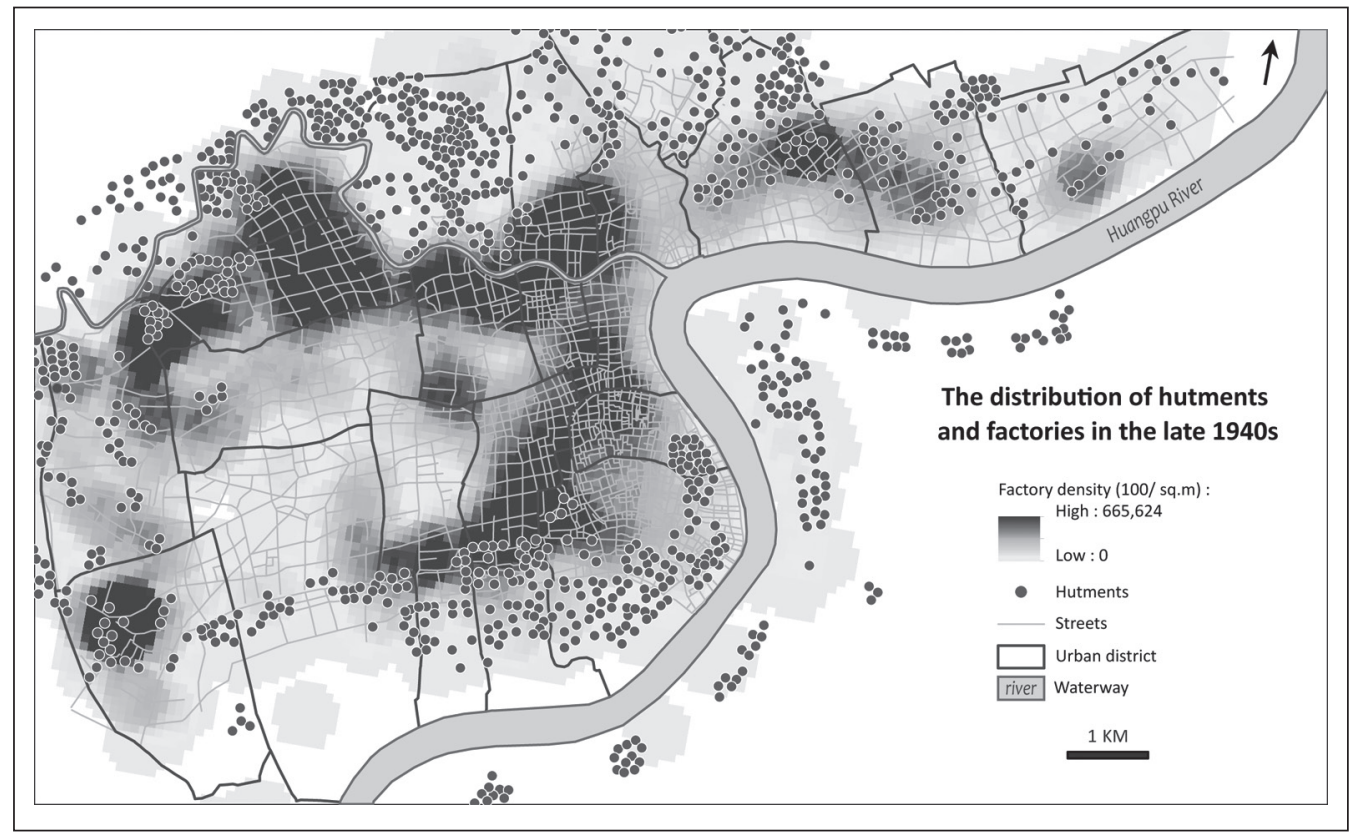

Map 10. The distribution of hutments and factories in the late 1940s.

The distribution of factories determined also a particular pattern of housing for the working classes. Although some large plants provided dormitories to their workers, this was usually limited to single working women or men. ${ }^{62}$ Those who had families had to find accommodation by themselves, usually in the immediate vicinity of factories, in self-made sheds. ${ }^{63}$ During most of the republican period, very little effort was made to construct affordable housing for factory workers, not to mention the even poorer coolies, rickshaw pullers, and other less privileged groups. The result of this discrepancy - a growing industrial workforce and no scheme for cheap housing - during a period of massive influx of population (especially after 1946) was the growth of huge hutments (penghuqu). There is no reliable survey of hutments in postwar Shanghai. A survey was made some time around 1950 that reflected the situation that prevailed in the late 1940 s. ${ }^{64}$ I overlaid this survey map on my own data, albeit approximately. This uncovered an unmistakable parallel between the distribution of industrial establishments and hutments (Map 10). Although there were other populations in the hutments than industrial workers, the development of hutments after World War I and through the 1930s was clearly linked to the rise of industry in the city. The military conflict in 1937 caused a redistribution of factories that had a direct impact on the relocation of hutments in the city ${ }^{65} \mathrm{I}$ cannot fully document the same process on hutments for lack of data, but it is safe to assume that workers played a major role in the (re)location of hutments in postwar Shanghai.

\section{Concluding Remarks}

By mid-1947, when the survey I used in this study was completed, Shanghai industries and more generally the whole economic system were on the verge of quickly sliding down to a frenzy state of disruption and collapse. In this context, industrialists had little alternative but to resort to protective tactics - which officials labeled as "hoarding" - and make use of their capital in ventures that veered away from investment and production-which again was labeled as "speculation." 
Whether one should consider this as profit seeking, even greed, or rational economic behavior, industrialists had no control on the whirlpool that was dragging them down. They had demonstrated their capacity to bounce back right after the end of the war and to push up industrial production to new heights, with the emergence of hundreds of new companies. Yet the process was not sustainable under the conditions of high and then hyperinflation. On the opposite, hyperinflation killed the momentum. Despite its regulatory powers and its control of a substantial share of the cotton industry, the national government utterly failed in creating the conditions for industrial development. It was not even a nascent developmental state at work; it was a debilitated and inefficient state apparatus, with a group of high officials like Song Ziwen vying for salvaging whatever they could for their own sake. ${ }^{66}$

From a spatial perspective, the present study relied on data "frozen in time." This is a photograph that clearly established that industry had colonized the urban space, even taking account the relative distance that kept one of the two major concentrations, Yangshupu, at bay, away from the core urban districts. Yet it is obvious that the second concentration in the western part of the city was located within a perimeter that was urban in nature. This was indeed the city intra muros. How much of this development can be attributed to the Sino-Japanese War period and how much to the short postwar period under study (1945-1947) is impossible to determine for lack of data for the earlier period, except for the International Settlement. Yet even for this area, I do not have a survey that would show the distribution of industries in early 1945. Administrative instability and the defective enforcement of regulations must have played a role, but industrialists did not select the location of their premises solely on the basis of regulatory factors. Cost considerations and business opportunities need to be factored in. This is something that I am not able to do at this stage.

From spatial reading, it is reasonable to hypothesize on a "linkage effect" as an explanatory factor for the distribution of some factories, due to their mutual needs. The size and nature of production also played a role as dependent variables that would definitely push large plants with a need for a large track of land and smooth communications away from the central districts. For many small workshops, however, these considerations were much less decisive. On the opposite, distance and costs of transportation probably offset the higher rent of premises in the more central locations. The next step in this direction will be to match industrial land occupation with land value data. This may give a better sense of the rent factor in industrial location. The level of technology and skills, which varied greatly, and consequently the level of salary also need to be factored in. Higher wages meant the possibility for workers to find accommodation in the city, whereas low-skilled workers ended up in hutments at the periphery.

Throughout the article, I have pointed out how much historians remain highly dependent on the nature of their sources, which translates into how they can avail themselves of the potential of GIS. The discontinuities in series, the lack of adequate cartographic materials, and the painfully slow process in locating items that run into the thousands are definitely daunting problems. At each step, one stumbles upon a "missing link," leaving one with hardly more possibility than to hypothesize or speculate. Nevertheless, GIS also has a higher value as a repository of data in which strata of data accumulate once and for all. It also implies that H-GIS can mean only "longterm" project. A couple of layers will not do the trick beyond providing a preliminary sense of "where was what." To figure out whether there was a deeper embedded pattern, to dig out clues about the significance of a given spatial distribution, and to assess how much weight we should give to "space" in our historical interpretation are other serious challenges.

The use of a large amount of data as in this article, which borders on the "quantitative" side of both history and GIS, is no guarantee that this can lead to path-breaking discoveries. At the same time, it does establish our knowledge — in this case, industries in the city — on a much more solid footing than mere statistics or more impressionistic data from newspapers and official reports. One potential use of this approach will be to process in GIS the instances of labor movements that 
erupted in Shanghai during the civil war. There is a good record of strikes and lockouts in the press and in police reports, with details about location, date, duration, number of workers involved, results, police action, spill over, etc., which may be linked to other factors such as price indexes and inflation. ${ }^{67}$ Somehow, we can pursue a study of labor unrest in a most troubled period in relation with the location, nature, and size of industrial plants. With all the limitations I mentioned above, GIS allows us to place industries in the city and link it to a large array of factors (workforce, nationality, etc.) that will definitely shed a brighter light on our knowledge of Shanghai's industrial dynamics in the past.

\section{Declaration of Conflicting Interests}

The author declared no potential conflicts of interest with respect to the research, authorship, and/or publication of this article.

\section{Funding}

The author disclosed receipt of the following financial support for the research, authorship, and/or publication of this article: The author wishes to thank the Chiang Ching-kuo Foundation for International Scholarly Exchange for its support to the "Cities in turmoil" project. The present paper is one of the outcomes of this project.

\section{Notes}

1. This is the second installment of a study of Shanghai industries in times of turmoil. The first part dealt with the 1936-1940 period. In that study, I took 1936 as a point of reference to examine the transformation of the industrial structure under the impact of war, using a two-pronged approach: one focused on a statistical analysis of the data, and one focused on the spatial dynamics of that transformation. Christian Henriot, "Regeneration and Mobility: The Spatial Dynamics of Industries in Wartime Shanghai", Journal of Historical Geography, vol. 38, no. 2, 2012, pp. 167-180.

2. On the political and military dimensions of the Civil War, see Michael Lynch, The Chinese Civil War 1945-49 (Oxford: Osprey Publishing, 2010); John F. Melby, The Mandate of Heaven Record of a Civil War; China 1945-49 (Toronto: University of Toronto Press, 1968); Suzanne Pepper, Civil War in China: The Political Struggle, 1945-1949 (Berkeley: University of California Press, 1978).

3. Chen Gongbo had been a major proponent of "controlled economy" before the war in a broader intellectual and political context that favored strong state intervention in the economy. Yet even the halfhearted attempts to enlist the Jiangnan business elite had met with reluctance and resistance. Moreover, the efforts at economic rationalization were debased by Jiang Jieshi's arbitrary decisions in favor of channeling resource to the military. Margherita Zanasi, Saving the Nation: Economic Modernity in Republican China (Chicago: University of Chicago Press, 2010), 46-49, 114-19.

4. Christian Henriot, "Shanghai Industries under Japanese Occupation: Bombs, Boom, and Bust (19371945)," in In the Shadow of the Rising Sun: Shanghai under Japanese Occupation, ed. Christian Henriot and Wen-Hsin Yeh (New York; Cambridge: Cambridge University Press, 2004), 17-45; Christian Henriot, "Rice, Power and People: The Politics of Food Supply in Wartime Shanghai (19371945)," Twentieth-Century China 26, no. 1 (n.d.): 41-84. On the situation in the lower Yangzi area, see Meizhen Huang, Ri wei dui Huazhong lunxian qu jingji de lüeduo yu tongzhi (Beijing: Shehui kexue wenxian chubanshe, 2005). In February 1945, the Bankers' Weekly had made a somber assessment of the system of controlled economy. Tang Xinyi, "Yi nian lai zhi wuzi tongzhi," YHZB (Bankers'Weekly) 29, no. 5-8 (February 1945): 6-10.

5. Zhaosan Sheng, "Minyuan lai shanghai zhi wujia zhishu," YHZB 31, no. 17. Rampant inflation reached catastrophic levels in 1943 (500 percent), 1944 (800 percent), and the first six months of 1945 (2,400 percent).

6. Xinyi Tang, "Dangqian gongshangye zhi weiji," YHZB 29, no. 21-24 (June 1, 1945): 6-9.

7. Zujing Yang, "1945 nian Shanghai renmin huanqing kangzhan shengli," Shiji, no. 5 (2005): 41.

8. "Diaocha: kangzhan qian hou zhi shanghai gongye tongji," YHZB 30, no. 5-6 (February 1, 1946): 16-17. 
9. Guanyao Xiao, "Yi nian lai de shanghai gongshang qiye," YHZB 29, no. 9-12 (March 1, 1945): 5-11.

10. After 1943, the publication of electrical consumption figures was prohibited. Tian Heqing, "Shanghai zhi zhanshi gongye," YHZB 31, no. 6-7 (February 17, 1947): 21.

11. Xiao, "Yi nian lai de shanghai gongshang," 10.

12. "Diaocha," 16.

13. Heqing Tian, "Shengli qian hou zhi shanghai gongshangye," YHZB 30, no. 7-8 (February 16, 1946): $5-7$.

14. One author claimed China had only three years to get ready for Japanese and Indian competition in the cotton industry. Shuyuan Feng, "Minyuan lai wo guo zhi mianfang zhigong," YHZB 31, no. 4-5 (February 3, 1947): 21.

15. Tian, "Shengli qian hou," 5-7; Linsun Cheng, "Zhongguo jihua jingji de qiyuan yu ziyuan weiyuanhui," Ershiyi Shiji Yuekan, no. 82 (April 2004): 95.

16. Shenbao, March 27, 1946, 6.

17. Shenbao, March 29, 1946, 6 .

18. Shenbao, March 30, 1946, 6.

19. Zanasi, Saving the Nation, 198-99.

20. “Zai wei zhongguo gongye huyu!” Shenbao, April 22, 1946.

21. Shenbao, October 23, 1946, 5.

22. Shenbao, June 24, 1947, 4.

23. "Shanghai jieyue yongdian banfa," YHZB 30, no. 38 (September 22, 1947): 30.

24. Feng, "Minyuan lai wo guo zhi mianfang zhigong," 20; Zijia Wang, "Yi nian lai wo guo zhi mianye," YHZB 32, no. 7-8 (February 23, 1948): 22-26.

25. After the war, the Chinese government confiscated 292 large- and middle-sized companies throughout China and Taiwan. Cheng, "Zhongguo Jihua Jingji de Qiyuan Yu Ziyuan Weiyuanhui," 94.

26. Kan Zhang, "Shilun 1945-1949 nian guomin zhengfu de waizhai guanli fagui jianshe," Zhongguo Jingjishi Yanjiu, no. 1 (2008): 154-59.

27. Zhangli Hong, "Yi nian lai zhi wo guo zhi gongye," YHZB 32, no. 4 (January 26, 1948): 9-19.

28. "Yuanliao xian'e fenpeiquan gongyejie zhengde yi ban," YHZB 31, no. 35 (September 1, 1947): 61.

29. Cheng, "Zhongguo jihua jingji.

30. Yueqin Tao, "Shanghai gongye de zhenxian dongyao le," YHZB 32, no. 30 (July 26, 1948): 17-18.

31. Shenbao, December 17, 1948, 2.

32. Sheng, "Minyuan lai shanghai zhi wujia zhishu."

33. Alain Roux, "Le Guomindang et les ouvriers de Shanghai (1938-1948): La déchirure," Le Mouvement Social, no. 173 (1995): 69-95.

34. “Gongye taobi de zai cuowu," YHZB 32, no. 3 (May 17, 1948): 3.

35. Lianhe zhengxinsuo diaochazu, Shanghai zhizao changshang gailan (Shanghai: [Lianhe zhengxinsuo], 1947).

36. The history of credit agencies in China can be traced back to the early 1930s. Shanghai was the seat of five foreign-run credit agencies. On June 6, 1932, Zhang Naiqi, a Chinese banker, started the China Credit Agency with the support from a number of Chinese-funded financial institutions. It was the first Chinese agency fully devoted to economic information. The fate of Chinese credit agencies, however, suffered from the subsequent Japanese invasion. In the later part of the war, in March 1945, a number of government-run financial institutions formally established the Union Credit Agency in Chongqing. After the Japanese surrender, the agency moved its headquarters to Shanghai and gradually set up branch offices in Hankou, Nanjing, Tianjin, Peking, Nanchang, and Shenyang. Zhang Shiqing, "Zhongguo qiye zhengxinye de fazhan lishi, xianzhuang he qushi," Caijingjie 10 (2005): 82-84.

37. Lianhe zhengxinsuo, Shanghai jinrongye gailan (Shanghai: Lianhe zhengxinsuo, 1947); Lianhe zhengxinsuo, Tuchan jieshao (Shanghai: Lianhe zhengxinsuo, 1951). On the Union Credit Information Agency and a similar body established earlier, see Zhiling Zhuang, "Zhongguo di yi jia guanban zhengxin jigou lianhe zhengxinsuo de xingshuai," Minguo dang'an [Republican Archives], no. 2 (2005): 80-86; “Zhongguo zhengxinsuo ji qi xinyong diaocha," Dang'an yu shixue [Archives and History], no. 6 (2003): 44-50.

38. Shanghai guohuo changshang minglu [The Shanghai Manufacturers' Directory] (Shanghai: Shanghai shi shanghui, 1946). 
39. Tiesun Liu, Jiadong Wang, and Dajun Liu, Shanghai guohuo gongchang diaochalu (Shanghai: Zhongguo jingji tongji yanjiusuo, 1934).

40. Cheng, "Zhongguo jihua jingji de qiyuan yu ziyuan weiyuanhui," 94.

41. "Diaocha," 16.

42. Shanghai shi hanghao lutu lu, vol. 1-2 (Shanghai: Fuli wenhua shiye youxian gongsi, 1947).

43. Henriot Christian, "Regeneration and Mobility," 167-80.

44. See the classic study by Marie-Claire Bergère, The Golden Age of the Chinese Bourgeoisie, 1911-1937 (Cambridge; New York: Cambridge University Press, 1989).

45. The Chinese central government rebuilt from scratch an entire industrial infrastructure, even if by 1945 the total production amounted to 12 percent of the national total. Cheng, "Zhongguo Jihua Jingji de Qiyuan Yu Ziyuan Weiyuanhui," 94. On the war industrial effort, see Morris L. Bian, The Making of the State Enterprise System in Modern China: The Dynamics of Institutional Change, (Cambridge, MA: Harvard University Press, 2005).

46. Cheng, "Zhongguo jihua jingji de qiyuan yu ziyuan weiyuanhui," 94.

47. Ibid., 98 .

48. On the Rong family and the Shenxin Group, see Parks M. Coble, "Chinese Capitalists in Wartime Shanghai, 1937-1945: A Case Study of the Rong Family Enterprises," in Henriot and Yeh, In the Shadow of the Rising Sun, 46-65; Parks M. Coble, Chinese Capitalists in Japan's New Order: The Occupied Lower Yangzi, 1937-1945 (Berkeley: University of California Press, 2003), chap. 6.

49. Bulletin d'informations économiques, March 13, 1939, 1, Box 45, Consulat général de Shanghai, Archives diplomatiques, Nantes; Weekly economic report, Consular Trade Report, September 7, 1940; Shanghai Business Barometer (February 1941); Consular Trade Report, March 31, 1941, RG59.3.7, Box1591, NARA (National Archives and Records Administration); Bulletin mensuel des services de police, February 1941, 71; September 1941, 61 and 72, Série E Vichy-Asie 1940-1944, Archives diplomatiques, Paris.

50. The city used to rely on domestic coal from North China and from nearby Anhui province. After the Japanese seizure of the northern provinces, Shanghai had to turn to imports from India, Borneo, and Indochina, a venue that disappeared almost completely after summer 1941. The share of imports increased tremendously, from 137,505 tons in 1937 to 789,207 in 1938; 950,075 in 1939; 1,366,482 in 1940; and 1,497,363 by November 1941. Chunxi Wu, "Shanghai gongshang dongtai zhi," Zhongguo jingji 2, no. 2, (1944): 23; "Shanghai meijin xiaofei shichang zhi fenxi," Zhongguo gongye yuekan [China Industrial Monthly] 1, no. 6 (1943): 29-36.

51. Yangrao Pan, "Shanghai gongye fuxing wenti," Zhongguo gongye yuekan 1, no. 2 (1943): 3-4.

52. Wu, "Shanghai gongshang dongtai zhi," 19.

53. In the two settlements, concerns for food supply and an increasing destitute population drove the authorities to initiate an ambitious plan for the repatriation of the population to the countryside, although with a limited success. See "Jiuji weiyuanhui, 1941-1942," U1-16-998-1007, Shanghai Municipal Archives; for a public view, see Shanghai Times, January 9, 14, 15, 17, 21, 28, and 29, 1942; February 5, 11, 17, 18, and 26, 1942.

54. Yizong Wang, "Zengchan nian zhong de gongye jianchan qingkuang," Zhongguo jingji 2, no. 9 (1944): 1.

55. Chang Kia-ngau, The Inflationary Spiral. The Experience in China, 1939-1950 (Cambridge, MA: Technology Press of the MIT, 1958), 383.

56. Tian, "Shanghai zhi zhanshi gongye," 23.

57. Maurice Daumas and Jacques Payen, Évolution de la géographie industrielle de Paris et sa proche banlieue au XIXe siècle (Paris: Conservatoire des arts et métiers, École des hautes études en sciences sociales, 1976); Jean Luc Pinol and Maurice Garden, Atlas des Parisiens, de la Révolution à nos jours (Paris: Parigramme, 2009).

58. James H. Bater, St. Petersburg: Industrialization and Change (Montreal: McGill-Queen's University Press, 1976), 92-100, 228-53.

59. This is the main argument made by Zhengshu Chen, "Zujie yu jindai Shanghai gongye de san da zhizhu," Shilin, no. 3 (2002): 74-80.

60. Edward K. Muller, "Industrial Suburbs and the Growth of Metropolitan Pittsburgh, 1870-1920," Journal of Historical Geography 27, no. 1 (January 2001): 58-73. 
61. Frederic E. Wakeman, The Shanghai Badlands: Wartime Terrorism and Urban Crime, 1937-1941 (Cambridge; New York: Cambridge University Press, 1996).

62. Emily Honig, Sisters and Strangers: Women in the Shanghai Cotton Mills, 1919-1949 (Stanford: Stanford University Press, 1986).

63. Christian Henriot, "Slums, Squats or Hutments? Constructing and Deconstructing an In-Between Space in Modern Shanghai (1926-1965)," Frontiers of History 7, no. 2 (2012): 499-528.

64. Yiren Zou, Jiu Shanghai renkou bianqian de yanjiu (Shanghai: Shanghai renmin chubanshe, 1980).

65. Henriot, "Slums, Squats or Hutments?

66. Cheng, "Zhongguo jihua jingji de qiyuan yu ziyuan weiyuanhui," 96.

67. Alain Roux, "Le Guomindang et les ouvriers de Shanghai," 69-95; Alain Roux, Le Shanghai ouvrier des années trente: coolies, gangsters et syndicalistes (Paris: Editions L'Harmattan, 1993).

\section{Author Biography}

Christian Henriot is a professor of Chinese history at the Lumière-Lyon 2 University and a senior research fellow at the Institut Universitaire de France. He is the author and editor of several books on modern Chinese history, including Prostitution and Sexuality in Shanghai: A Social History, 1849-1949 (Cambridge University Press, 2001), In the Shadow of the Rising Sun: Shanghai under Japanese Occupation (Cambridge University Press, 2004), and Visualizing China (Brill, 2013). He is also the editor of a digital research and resource platform on Shanghai history (http://virtualshanghai.net). 